\title{
Lignin Model Compounds. I. The Synthesis of Glyceraldehyde 2-Aryl Ethers
}

\author{
T. A. HASE, ${ }^{a}$ LEILA LAHTINEN ${ }^{a}$ and A. KLEMOLA ${ }^{b}$
}

a Department of Chemistry and $b$ Department of Forest Products, Helsinki University of Technology, SF-02150 Espoo 15, Finland

Two improved synthetic routes to the title compounds are described. The reaction of a substituted phenolate ion with 2-bromo-3buten-1-ol (or its acetate, or the acetate quaternised with $N, N$-dimethylaniline) gives a mixture of $\mathrm{S}_{\mathrm{N}} 2$ and $\mathrm{S}_{\mathrm{N}} 2^{\prime}$ substitution products along with the 2-butene-1,4-bisaryl ether. Ozonation of 2-aryloxy-3-buten-1-ol produces the dimeric glyceraldehyde 2-aryl ether. More conveniently, the same product is obtained by addition of the phenolate ion to 4,4 . dimethyl-3,5,7-trioxabicyclo[5.1.0]octane (i.e., epoxidised cis-2-butene-1,4-diol acetonide), followed by acetonide cleavage and periodate oxidation.

Structural units in wood lignins seem to include some detached glyceraldehyde units. Based on what is known of the reactions in lignin biosynthesis, these units should mainly be linked to the rest of the lignin macromolecule through a 2-aryl ether bond (1). ${ }^{1}$ Experimental evidence for the existence of such groupings in lignins has been provided by the formation of pyruvic aldehyde both from lignin and from an appropriate model compound (2) in mild acidolysis ${ }^{2,3}$ and in an acid sulfite cook, ${ }^{4}$ and by the formation of 2-(2-methoxy-4-propyl) phenoxy-1propanol in wood hydrogenolysis. ${ }^{5}$ Lundquist et $a .^{2,3}$ have synthetised the lignin model compound 2 in a low yield by condensing 2 -aryloxy acetaldehyde with formaldehyde.

We have developed alternative synthetic routes to lignin model compounds of type 2 . In the first of these, the aryl alkyl ether linkage is formed in a substitution reaction of 3 or 4 with the phenolate ion $\mathrm{ArO}^{-}$(5). Subsequent ozonation of the product gives the glyceralde. hyde unit in good yield.

Acta Chem. Scand. B 31 (1977) No. 6
The substitution of a halide in 2-halo-3. buten-1-ol with 2-methylphenolate anion in $32 \%$ yield has been described by Yale et al. ${ }^{\circ}$ They do not, however, comment on the $\mathrm{S}_{\mathrm{N}} \mathbf{2}^{\prime}$ substitution which we found to accompany the main reaction (see Scheme). Along with 6 and 8 the diether 10 was unexpectedly also isolated from the reaction of 3 with 5 .

The highest yield of the $\mathrm{S}_{\mathrm{N}} 2$ substitution product $\boldsymbol{\gamma}$ was obtained when the acetoxy bromide 4 was converted into a quaternary ammonium salt (11) prior to the reaction. Significantly more of the $\mathrm{S}_{\mathrm{N}} 2^{\prime}$ substitution product ( 8 or 9 , characterised by oxidation to the corresponding aldehyde) resulted from the direct use of 3 or 4 .

Ozonation of 6 (from hydrolysis of 7) gave the aldol 2 as a viscous oil without $\mathrm{C}=\mathrm{O}$ absorption bands in the IR spectrum as previously reported.2,3 The aldol was reduced by sodium borohydride to the corresponding 2-aryl glycerol ether. ${ }^{3}$

The aldol 2 actually has the dimeric 1,3dioxane structure 12; structurally simpler aldols are well known ${ }^{7}$ to exist as 1,3-dioxan type cyclic dimers. This was shown by silylation of the aldol to give the protected derivative 13 having spectral data in accord with the structure indicated. In particular, the Eu-FOD resolved ${ }^{1} H$ NMR spectrum showed that the sample had four different aromatic methyl groups in pairs of two (ratio ca. 1:2). As the silicon-bonded oxygens of 13 will not coordinate europium, ${ }^{8}$ there remain six other potential coordinative oxygen atoms in the molecule. However, it is unnecessary to know where exactly the metal atom is located as it is known 

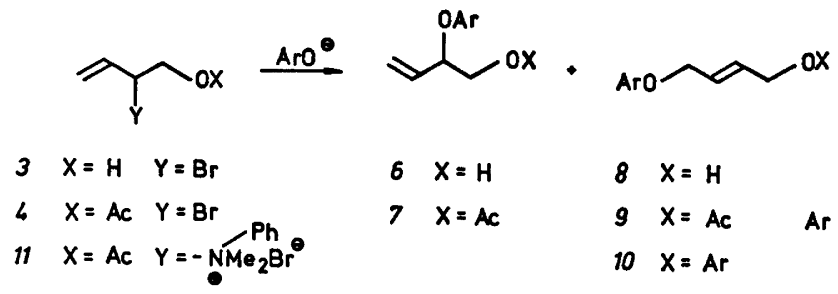

$6 x=H$

$7 \quad X=A C$

$8 \quad x=H$
$9 x=A C$
$10 x=A r$<smiles>COc1cc(C)ccc1C</smiles>

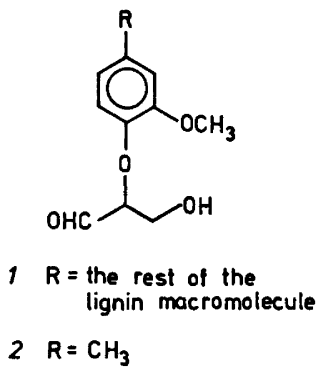<smiles>[X]OCC(O)C1OCC(OC(=O)OCc2ccccc2)C(O[X])O1</smiles>

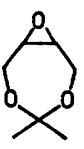

14<smiles>COc1cc(C)ccc1OC1COC(C)(C)OCC1O</smiles>

15 that $\mathrm{Eu}(\mathrm{DPM})_{3}$ induced shifts are simply additive with bioxygen functional molecules.' Thus the observed four aromatic methyl signals undoubtedly indicate that at least two stereoisomers of the substituted 1,3-dioxane ring are present. Although large shifts were observed for the dioxan ring protons (and incidentally, less so for the methoxyl protons, showing that these groups are not primarily involved in Eu coordination) the overlapping signals of the isomers remain sufficiently complex to obscure the stereochemistry of the dioxane substitution.

The above lengthy route to 2 requires a tedious separation of intermediates. Therefore, another route to 2 was examined. The oxido ketal 14, readily available ${ }^{10}$ from cis-2-butene1,4-diol, undergoes attack by the phenolate ion 5 to give 15 in $60 \%$ yield. Owing to the symmetric nature of 14 , no problems of regioselectivity of epoxide opening are encountered. The acetonide protective group is then removed and the vic-diol system cleaved by periodate oxidation in a one-pot reaction to give the aldol 2 (91\% yield from 15$)$.

\section{EXPERIMENTAL}

The following analytical instruments were used: Perkin Elmer 125 (IR), Varian A-60 or
Jeol PMX 60 (' ${ }^{1} \mathrm{H} \mathrm{NMR,} \mathrm{CDCl}_{3}$ solvent), PerkinElmer $270 \mathrm{~B}$ (MS) and F \& M CHN Analyser 185. 2-Bromo-3.buten-1-ol (3).11 NMR: $\delta \quad 5.9$ $(1 \mathrm{H}, \mathrm{m}), 5.2(2 \mathrm{H}, \mathrm{m}), 4.5\left(1 \mathrm{H}, \mathrm{dt}, J_{1}=8.5 \mathrm{~Hz}\right.$, $\left.J_{2}=6 \mathrm{~Hz}\right), 4.7(2 \mathrm{H}, \mathrm{d}, J=6 \mathrm{~Hz}), 3.2(1 \mathrm{H}, \mathrm{s})$. 2-Bromo-3-buten-1-yl acetate (4).11 NMR: $\delta 6.1(1 \mathrm{H}, \mathrm{m}), 5.25(2 \mathrm{H}, \mathrm{m}), 4.7(1 \mathrm{H}, \mathrm{dt}$, $\left.J_{1}=8 \mathrm{~Hz}, J_{2}=5.5 \mathrm{~Hz}\right), 4.35(2 \mathrm{H}, \mathrm{d}, J=5.5 \mathrm{~Hz})$, $2.05(3 \mathrm{H}, \mathrm{s})$.

2.(2-Methoxy-4-methylphenoxy)-3-buten-1-ol

(6). 2-Methoxy-4-methylphenol $(9.1 \mathrm{~g})$ was dissolved in $100 \mathrm{ml}$ of dry dioxane (dried over $\mathrm{CaH}_{2}$ ), $3.2 \mathrm{~g}$ of a $50 \% \mathrm{Na}$-dispersion in paraffin oil were added, and the mixture was stirred for $2 \mathrm{~h}$. After adding $9.1 \mathrm{~g}$ of 3 in $20 \mathrm{ml}$ of dry dioxane, the stirring was continued overnight. The mixture was poured into water and ex. tracted with ether. The ether solution was washed with $10 \% \mathrm{KOH}$, and with brine, dried, and concentrated. Dry column chromatography on Silica gel Woelm with $\mathrm{CHCl}_{3}$-light petroleum (1:1) gave three fractions:

(a) $1.19 \mathrm{~g}$ of 10, m.p. $106^{\circ} \mathrm{C}$ (EtOH), NMR: $\delta 2.27(6 \mathrm{H}, \mathrm{s}), 3.78(6 \mathrm{H}, \mathrm{s}), 4.47(4 \mathrm{H}, \mathrm{br} \mathrm{s})$, $6.00(2 \mathrm{H}, \mathrm{m}), 6.58(6 \mathrm{H}, \mathrm{br} \mathrm{s})$ [reported ${ }^{12}$ for 1,4-diphenoxy-2-butene: $4.5(\mathrm{~s}), 6.0(\mathrm{t}), 6.7-7.4$ (m)], MS (70 eV): $m / e \quad 328\left(48.8 \%, \mathrm{M}^{+}\right), 191$ (47.2, M-ArO), 190 (46.8, M-ArOH), 138 (61.4, ArOH), 137 (100, ArO), 109 (80, methylmethoxy-cyclopentadienyl).

(b) $5.5 \mathrm{~g}(40 \%)$ of 6 as an oil. Anal. $\mathrm{C}_{12} \mathrm{H}_{18} \mathrm{O}_{3}$ : C, H. IR (film): $3640,1030,990$, and $925 \mathrm{~cm}^{-1}$. NMR: $\delta 6.6(3 \mathrm{H}, \mathrm{m}), 5.8(1 \mathrm{H}, \mathrm{m}), 5.2(2 \mathrm{H}, \mathrm{m})$, $4.5\left(1 \mathrm{H}, \mathrm{dt}, J_{1}=5.5 \mathrm{~Hz}, \mathrm{~J}_{2}=5 \mathrm{~Hz}\right), 3.65(3 \mathrm{H}$, $\mathrm{s}), 3.7(2 \mathrm{H}, \mathrm{m}), 2.2(3 \mathrm{H}, \mathrm{s})$.

(c) $3.45(25 \%)$ of 8 as an oil. Anal. $\mathrm{C}_{12} \mathrm{H}_{18} \mathrm{O}_{3}$ : C, H. IR (film): $3400,1000,965$ (trans), and 
750 (cis) $\mathrm{cm}^{-1}$. NMR: $\delta 6.65(3 \mathrm{H}, \mathrm{m}), 5.85$ (2 H, m), $4.45(2 \mathrm{H}, \mathrm{m}), 4.05$ (2 H, m), 3.75 (3 H, s), $2.25(3 \mathrm{H}, \mathrm{s})$.

2-(2-Methoxy-4-methylphenoxy)-3-butenyl acetate (7). A. 2-Methoxy-4-methylphenol (7.75 g) was treated as above with $10.0 \mathrm{~g}$ of 4 . Dry column chromatography on Silica gel Woelm with $\mathrm{CHCl}_{3}$-light petroleum $(1: 5)$ gave two fractions:

(a) $4.2 \mathrm{~g}(30 \%)$ of 7 as an oil. Anal. $\mathrm{C}_{14} \mathrm{H}_{18} \mathrm{O}_{4}$ : C, H. IR (film): 1740,990 , and $930 \mathrm{~cm}^{-1}$. NMR: $\delta 6.8(3 \mathrm{H}, \mathrm{m}), 5.9(1 \mathrm{H}, \mathrm{m}), 5.3(2 \mathrm{H}, \mathrm{m})$, 4.85 ( $1 \mathrm{H}, \mathrm{q}, J=6 \mathrm{~Hz}), 4.25(2 \mathrm{H}, \mathrm{d}, J=6 \mathrm{~Hz})$, $3.8(3 \mathrm{H}, \mathrm{s}), 2.2(3 \mathrm{H}, \mathrm{s}), 1.95(3 \mathrm{H}, \mathrm{s})$.

(b) $2.1 \mathrm{~g}(15 \%)$ of 9 as an oil. Anal. $\mathrm{C}_{14} \mathrm{H}_{18} \mathrm{O}_{4}$ : C, H. IR (film): 1740,970 , and $715 \mathrm{~cm}^{-1}$. NMR: $\delta 6.7(3 \mathrm{H}, \mathrm{m}), 5.8(2 \mathrm{H}, \mathrm{m}), 4.55(2 \mathrm{H}, \mathrm{m}), 4.0$ ( $2 \mathrm{H}, \mathrm{m}), 3.7$ (3 H, s), $2.2(3 \mathrm{H}, \mathrm{s}), 2.0(3 \mathrm{H}, \mathrm{s})$.

B. $4(8.0 \mathrm{~g})$ was dissolved in $50 \mathrm{ml}$ of dried dioxane. $5.5 \mathrm{~g}$ of $N, N$-dimethylaniline were added, and the mixture was left to stand overnight. The mixture was added to the phenolate. solution 5 , made from $6.3 \mathrm{~g}$ of 2 -methoxy-4methylphenol as above. The mixture was stirred overnight and worked up as above. Dry column chromatography yielded 6.85 of $7(60 \%)$ and $2.6 \mathrm{~g}$ of $9(23 \%)$.

4-(2-Methoxy-4-methylphenoxy)-2-buten-1-al. $8(2.0 \mathrm{~g})$ was dissolved in acetone and treated with Jones' reagent. Normal work-up yielded $1.4 \mathrm{~g}(70 \%)$ of 4-(2-methoxy-4-methylphenoxy)-2-buten-1-al as an oil. Anal. $\mathrm{C}_{12} \mathrm{H}_{14} \mathrm{O}_{3}$ : C, H. IR (film): $1690,965 \mathrm{~cm}^{-1}$. NMR; $\delta 9.4$ (1 H, d, $J=7.5 \mathrm{~Hz}$ ), 6.6 ( $5 \mathrm{H}, \mathrm{m}), 4.55$ (2 H, $\left.\mathrm{dd}, J_{1}=4 \mathrm{~Hz}, J_{2}=2.5 \mathrm{~Hz}\right), 3.75(3 \mathrm{H}, \mathrm{s}), 2.25$ (3 H, s).

Hydrolysis of 2-(2-methoxy-4-methylphenoxy)3-buten-1-yl acetate (7). 7 (5.75 g) was refluxed for $2 \mathrm{~h}$ in $50 \mathrm{ml}$ of $80 \% \mathrm{EtOH}$, which contained $0.5 \mathrm{~g}$ of KOH. Normal work-up gave $4.5 \mathrm{~g}$ $(94 \%)$ of 6 .

2-(2-Methoxy-4-methylphenoxy)-3-hydroxypropanal (2). 6 (4.9 g) was dissolved in $50 \mathrm{ml}$ of $\mathrm{CH}_{3} \mathrm{OH}-\mathrm{CH}_{2} \mathrm{Cl}_{2}$ (1:1). An ozone-oxygen mixture was led through the solution at $-78^{\circ} \mathrm{C}$ until the starting material was consumed, as determined by TLC. Excess $\mathrm{O}_{3}$ was removed by an $\mathrm{N}_{2}$-stream, and $4.0 \mathrm{~g}$ of tris-dimethylaminophosphine were added to the solution. The mixture was allowed to stand for $2 \mathrm{~h}$ at room temperature, whereafter it was poured into water, the organic layer washed with dilute $\mathrm{H}_{2} \mathrm{SO}_{4}$ and water, dried, and evaporated. An oil (4.05 g, $82 \%$ ) was obtained after dry column chromatography on Silica gel Woelm with $\mathrm{CHCl}_{3}$-EtOAc (2:1). Anal. $\mathrm{C}_{11} \mathrm{H}_{14} \mathrm{O}_{4}: \mathrm{C}, \mathrm{H}$. IR (film): $3370 \mathrm{~cm}^{-1}$. NMR: $\delta 6.6(3 \mathrm{H}, \mathrm{m})$, $5.4-3.6$ (8 H, m), $2.2(3 \mathrm{H}, \mathrm{s})$.

Silylation of $2.2(0.42 \mathrm{~g})$ was dissolved in $5 \mathrm{ml}$ of dry DMF containing $0.64 \mathrm{~g}$ of imidazole. $1.34 \mathrm{~g}$ of $t$-butylchlorodimethylsilane was added and the mixture stirred for $14 \mathrm{~h}$. It was then poured into water $\left(0^{\circ} \mathrm{C}\right)$, the solution extracted twice with light petroleum (b.p. $40-50^{\circ} \mathrm{C}$ ) and the organic phase dried and evaporated. TLC and NMR showed that the residue consisted of a 1:1 mixture of 13 and the dehydration product of 2 , i.e., 2-aryloxyacrolein. ${ }^{3}$ Preparative chromatography failing to separate these two compounds, pure 13 was isolated as follows. The mixture $(0.69 \mathrm{~g})$ in $10 \mathrm{ml}$ of dry THF was stirred with $0.1 \mathrm{~g}$ of $\mathrm{NaBH}_{4}$. After $4 \mathrm{~h}, 2$-aryloxyacrolein was no longer detectable by TLC. Filtration through alumina provided pure 13 $(0.19 \mathrm{~g})$. NMR $\left(\mathrm{CCl}_{4}\right): \delta 0.07(12 \mathrm{H}, \mathrm{s}), 0.85(9$ $\mathrm{H}, \mathrm{s}), 0.90(9 \mathrm{H}, \mathrm{s}), 2.30$ ( $6 \mathrm{H}, \mathrm{br} \mathrm{s}), 3.82$ (6 H, $\mathrm{s}), 3.5-4.5(6 \mathrm{H}, \mathrm{m})(\mathrm{a}), 4.90(2 \mathrm{H}, \mathrm{m})(\mathrm{b})$, $6.5-7.15(6 \mathrm{H}, \mathrm{m})$. Successive additions of 0.1 equivalents of EuFOD to the solution produced large shifts with the signals (a) and (b) while all methyls and the aromatic multiplet remained fairly constant. In particular, at a $1: 1 \mathrm{~mol}$ ratio of 13 and EuFOD, aromatic methyl singlets appeared as follows: 1.95 (c), 2.04 (d), 3.11 (e) and 3.29 (f) with intensities c:d:e:f $=2: 1: 2: 1$. MS $(70 \mathrm{eV}): 648\left(15 \%, \mathrm{M}^{+}\right), 591(2, \mathrm{M}-t$-Bu), $381\left(9.9, \mathrm{M}-\left(\mathrm{ArO}+\mathrm{BuMe}_{2} \mathrm{SiOH}\right)\right), 353(14.2$, $\left.\mathrm{M}-\mathrm{ArOCHCH} \mathrm{OSiMe}_{2} \mathrm{Bu}\right), \quad 307 \quad(87.5), \quad 190$ (100), 175 (100). Anal. $\mathrm{C}_{34} \mathrm{H}_{56} \mathrm{O}_{8} \mathrm{Si}_{2}: \mathrm{C}, \mathrm{H}$.

2,2-Dimethyl-5-(2-methoxy-4-methylphenoxy)6-hydroxy-1,3-dioxepane (15). The oxido ketal $14^{10}(5.0 \mathrm{~g})$ was mixed with $6.0 \mathrm{~g}$ (1.25-fold excess) of 2-methoxy-4-methylphenol and 0.1 $\mathrm{ml}$ of $20 \%$ ethanolic $\mathrm{KOH}$. The solution was held at $110-120^{\circ} \mathrm{C}$ for $10 \mathrm{~h}$, cooled and taken up in ether. The ether solution was washed twice with $10 \%$ aq. $\mathrm{KOH}$, dried and concentrated. Crystallisation from ethanol gave $3.8 \mathrm{~g}$ of 15 , and the mother liquor furnished an additional $2.05 \mathrm{~g}$ of 15 on silica gel (Woelm) dry column chromatography with $\mathrm{CHCl}_{3}:$ EtOAc (9:1), the total yield thus being $60 \% .0 .95 \mathrm{~g}$ of cresol was recovered from the alkaline washings. The analytical sample was recrystallised from ethanol, m.p. $91-92^{\circ} \mathrm{C}$, IR (KBr pellet): $3430 \mathrm{~cm}^{-1}$. NMR: $\delta 1.33(6 \mathrm{H}, \mathrm{s}), 2.25$ (3 H, s), 3.1-4.1 (9 H, m), $6.7(3 \mathrm{H}, \mathrm{m})$. MS m/e: $282(7.1 \%, \mathrm{M}+), 267\left(1.2, \mathrm{M}-\mathrm{CH}_{3}\right)$, $145(3.5, \mathrm{M}-\mathrm{ArO}), 138$ (38.1, ArOH). Anal. $\mathrm{C}_{15} \mathrm{H}_{22} \mathrm{O}_{5}: \mathrm{C}, \mathrm{H}$.

2-(2-Methoxy-4-methylphenoxy)-3-hydroxypropanal (2) from $15.15(3.8 \mathrm{~g})$ was dissolved in $150 \mathrm{ml}$ of methanol, $0.1 \mathrm{~g}$ of $\mathrm{TsOH}$ added and the solution held for $20 \mathrm{~min}$ at $60^{\circ} \mathrm{C}$. TLC showed that no unreacted 15 remained at this stage. The solution was then cooled to $0^{\circ} \mathrm{C}$ and 150 $\mathrm{ml}$ of water added followed by $2.9 \mathrm{~g}$ of $\mathrm{NaIO}_{4}$. Stirring was continued for $2 \mathrm{~h}$ at $0{ }^{\circ} \mathrm{C}$ and $8 \mathrm{~h}$ at $20^{\circ} \mathrm{C}$. The bulk of methanol was removed (Rotavap), the residue poured on brine and extracted 4 times with ether. The combined extracts were dried and evaporated to give $2.57 \mathrm{~g}(91 \%)$ of 2 , freed from minor impurities by silica gel (Woelm) dry column chromatography with $\mathrm{CHCl}_{3}-\mathrm{EtOAc} 3: 1$. IR and NMR were identical with those of the material prepared as described above. 


\section{REFERENCES}

1. Sarkanen, K. V. In Sarkanen, K. V. and Ludwig, C. H., Eds., Lignins, Wiley, New York 1971, p. 95.

2. Lundquist, K., Miksche, G. E., Ericsson, L. and Berndtson, L. Tetrahedron Lett. (1967) 4587.

3. Berndtson, L., Hedlund, K., Hemrå, L. and Lundquist, K. Acta Chem. Scand. B 28 (1974) 333.

4. Christofferson, K. Sven. Papperstidn. 73 (1970) 566.

5. Klemola, A. and Pepper, J. M. Chem. Commun. (1969) 1048.

6. Yale, H. L., Pribyl, E. J., Braker, W., Bergeim, F. H. and Lott, W. A. J. Am. Chem. Soc. 72 (1950) 3710.

7. Späth, E. and Schmid, H. Ber. Dtsch. Chem. Ges. B 74 (1941) 859.

8. Hosoda, H., Yamashita, K. and Nambara, T. Chem. Ind. London (1975) 650.

9. Ius, A., Vecchio, G. and Carrera, G. Tetrahedron Lett. (1972) 1543.

10. Elliot, W. J. and Fried, J. J. Org. Chem. 41 (1976) 2469.

11. Petrov, A. A. J. Gen. Chem. USSR 11 (1941) 991; see Chem. Abstr. 37 (1943) 1699.

12. Thyagarajan, B. S., Balasubramanian, $K$. K. and Bhima Rao, R. Tetrahedron 23 (1967) 1893.

Received December 20, 1976. 